\title{
Assisting teachers' understanding of student learning in technology
}

\author{
Wendy Fox-Turnbull ${ }^{1}$
}

Accepted: 9 November 2018

(c) Springer Nature B.V. 2018

\begin{abstract}
This article describes a study undertaken in New Zealand, England and Sweden and is based on the use of a tool developed by the researcher as a professional development and teaching tool in technology education for teachers of students between four and six years of age. The aim of the research was to investigate teachers' views of the effectiveness of the tool designed to deepening their understandings of technology content and pedagogical content knowledge. The tool, technology observations and conversation framework (TOCF) was designed to guide teachers' interactions with and observations of young children when learning technology with the aim of developing teacher insight into their own understanding of technology and how students learn technology. The tool was developed using the building of learning power theory to facilitate the identification of key dispositions and attitudes within four aspects of learning and across five pre-determined behaviours relevant to technology education. Qualitative research methods were used to investigate teachers' interaction with the TOCF by observing their use of it, and interviewing them about their perceived developed understanding of technology content knowledge and pedagogical content knowledge (PCK). The initial purpose of the framework, presented to the teachers prior to teaching, was to guide interactions with students to assist this development and subsequently assist their ability to teach technology effectively and give specific feedback to students in technology education. The study found that teachers felt that they gained a deeper understanding of technology education and their understanding of students' learning in technology also developed. This article presents the final framework and teachers' views on how they were assisted by the framework. The study offers an international perspective on ways to broaden and deepen students' understanding in technological literacy through the development of teacher content knowledge and PCK and contributes significantly to the field of formative assessment in technology education.
\end{abstract}

Keywords Technology PCK $\cdot$ Technology education $\cdot$ ECE $\cdot$ Primary $\cdot$ Classroom conversation $\cdot$ Teacher development

Wendy Fox-Turnbull

wendy.fox@waikato.ac.nz

1 Faculty of Education, University of Waikato, Private Bag 3105, Hamilton 3240, New Zealand 


\section{Introduction}

Understanding technology education involves intelligent observation of and conversation with children by teachers with the purpose of improving students' technological literacy (Compton and France 2007). Understanding relevant behavioural and learning dispositions in the context of technology could be useful in assisting teachers' ability to understand and develop ideas of how students learn in technology. Learning in technology is not linear, but rather a holistic process which can be difficult to understand and assess (Kimbell 1997). Achievement in technology includes students' conceptual understandings of subject matter and their ability to transfer concepts to future learning in both new and unfamiliar situations (Pellergrino 2002). National or state curricula such as New Zealand's national curriculum technology achievement objectives (Ministry of Education 2007) and the United Kingdom's Key Stages (Department of Education 2013a) in design and technology (d\&t) go some way to identifying key ideas of technology and how they progress.

Compton and Harwood (2005), Jones (2009) and Pellegrino (2002) suggest more research is needed around the notion and specifics of learning in technology. In order to do this teachers need to have a deep understanding of technology content knowledge (TCK) and technology pedagogical content knowledge (TPCK).

The underpinning philosophy of technology education is that students design, develop and evaluate technological outcomes. To do this successfully it is necessary to situate technology within the human world, and identify and understand the impacts and influences technology has on people and their environment (de Vries 2017). An holistic approach is used, with learning occurring through a range authentic learning contexts (Snape and FoxTurnbull 2013; Turnbull 2002) and areas to solve technological problems (Department of Education 2013b; Ministry of Education 2007).

The research reported in this article investigated the effectiveness of targeted observations and questions in developing teachers' understanding of and ability to teach technology education. The aim was to develop teachers' TCK and TPCK, thus improving the quality of their feedback to students. The research was undertaken in three countries, New Zealand, England and Sweden, all with a high reputation in technology education. Teachers of four and six-year-old students, were given a tool based on a merger of the underlying philosophy of technology, the process of technology practice and desirable 21st Century learning behaviours. The technology observation and conversation framework (TOCF), informed teacher conversations with students while engaged in technological activity. The framework had two slightly different versions, the first was aimed at five to six-year olds and was informed by common aspects of technology from the three participating countries' technology curriculum for primary school children. The second was very similar but used slightly modified language to align with the early childhood curricula of the participating countries and was used by the teachers of four to five-year-old students.

\section{Literature review}

Cross (2011) presents a case for a constructivist approach to learning. As students construct their knowledge interaction with others plays a critical role. Numerous studies have investigated the role conversation or talk plays in learning (Alexander 2008; Clarke 2014; Mercer 1995; Mercer and Dawes 2008; Mercer and Hodgkinson 2008; Mercer and Littleton 2007; 
Shields and Edwards 2005). Many have also investigated the role it plays in learning technology (Fox-Turnbull 2016; Hope 2018; Masson et al. 2016; Osborne 2009). Yliverronen (2018) found that preschool students were able to work collaboratively on technology projects, but that their conversations were shorter and less complex than that of older children and adults, thus suggesting that conversation ability can be enhanced with assistance.

Development of a teacher's pedagogical content knowledge relies on and develops with sound content knowledge and pedagogical knowledge (Gudmundsdottir and Shulman 1987; Shulman 1986), as illustrated in the now well-known Shulman's TPACK Model seen in Fig. 1.

Fox-Turnbull (2006) and Moreland et al. (2001) found that teachers' TCK influences the quality of their teaching, as does that of their TPCK (Rohaan 2009). Technology PCK has been the focus of numerous recent studies (Doyle et al. 2018; Hulten and Bjorkholm 2016; Rohaan 2009; Williams et al. 2012). Hulten and Bjorkholm (2016) stated that teachers need both TCK and PCK to be able to teach technology. Doyle et al. (2018) found that PCK situates itself within specific teachers' experiences. PCK was defined by Shulman (1986) as the understanding of why certain materials are easy to learn and others hard. This varies according to the age of the students and the complexity of the content knowledge. It is particularly useful as classroom learning moves from a simple transmission style of learning to that the more complex student-centred, problem-solving model we are seeing in the 21st Century (Williams et al. 2012).

Claxton and Carr (2010) suggested that a number of learning dispositions, orientations or habits are advocated by educators for successful learning. The dispositions, or ways of

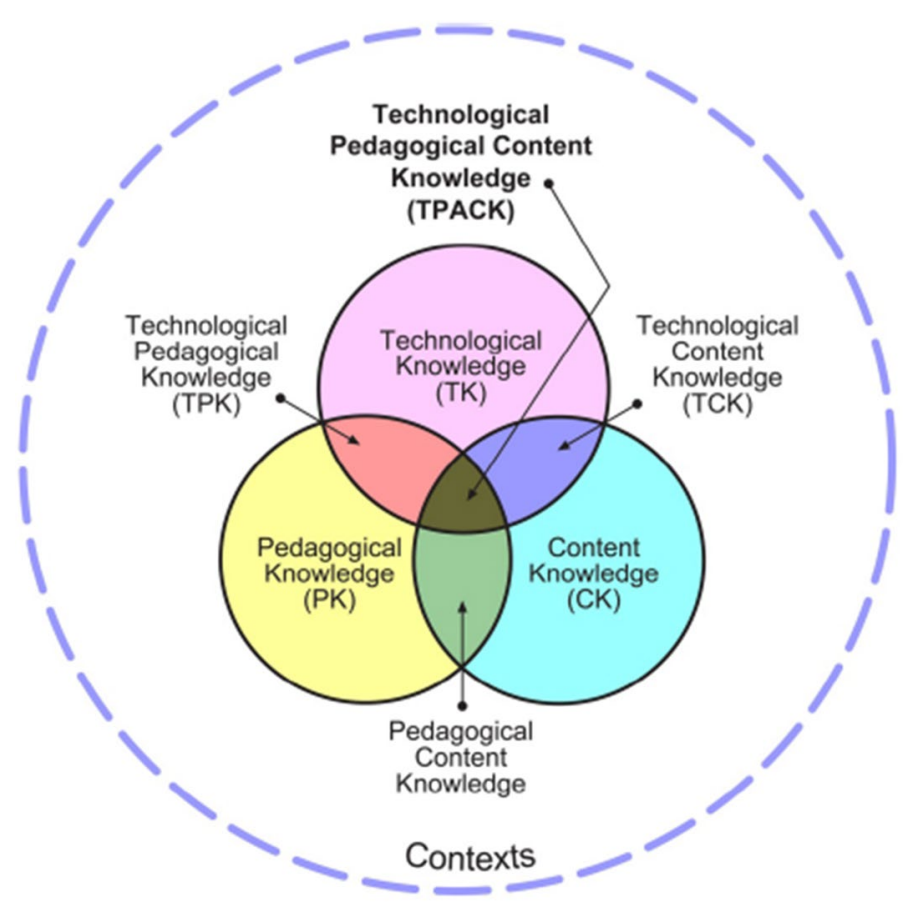

Fig. 1 The TPACK framework and its knowledge components (Gudmundsdottir and Shulman 1987) 
'doing', increase in frequency and complexity over time as students' progress. Claxton et al. (2013) discussed the building of 'learning power' within students through the development of dispositions and attitudes including the building of students' confidence and self-belief in their capabilities, within four domains of learning. Each of the four domains: resilience, resourcefulness, reflectiveness and reciprocity contained capabilities. Those particularly relevant to technology education included noticing, perseverance, managing distractions and absorption in the resilience domain; making links, questioning and imaging in Resourcefulness; planning and distilling in Reflectiveness and collaboration, empathy, inter-dependence in Reciprocity. Claxton et al. (2013) stated that increasing students' curiosity, sense of adventure, perseverance, and independence along with teaching students how to be better learners also increased their capabilities.

Moreland and Jones (2000) stated that formative assessment of technology occurred through a range of strategies such as observations, work samples and student portfolios of technology practice. Teachers understanding of technology and students' learning in technology developed as teachers listened, watched, and interacted with students. Continuous observations provided the basis of information for in-depth evaluation integral to making decisions on how best to understand students' learning and how best to meet their needs. Judgements should always be focused on individual students over a period of time and teachers should avoid comparisons between children (Ministry of Education 1996). In this research teachers used the TOCF as a tool to develop their TCK and TPCK and therefore to inform their formative understandings of students' learning in technology.

\section{Technology observation and conversation framework (TOCF)}

The TOCF was designed to bring together key ideas about learning: classroom talk, TCK, TPCK and 21 st Century dispositions and behaviours as a tool to assist teachers' teaching of technology. Investigation into the technology curricula in each participating country identified several common aspects. In primary these included students' ability to: gain an understanding of their technological world; evaluate (analyse and critique) current technologies; identify potential technological problems, needs or opportunities; design and make technological outcomes to meet identified needs using a range of materials, and to understand key concepts and processes unique to technology and deploy these in their practice where applicable. The early childhood curricula suggested children learn technology through: exploration of the 'made-world', communicating ideas about the made-world, independent engagement in and with technology, contributing to the made-world through making and construction in a range of areas and the development of resilience, resourcefulness, reflectiveness, reciprocity, a sense of self and of achievement when undertaking the above.

Based on the work by Claxton et al. (2013) and Claxton and Carr (2010) and the investigation of technology curricula key dispositions and competencies particularly relevant to technology were identified and clustered into five behaviours: resilience, transference, flexibility, reflection and socialisation. These behaviours incorporated cognitive, social and physical components. To assist understanding of each behaviour, specific capabilities were identified for each and are outlined in Table 1 and briefly explained.

Resilience included capabilities of perseverance especially after initial failure, managing distractions from peers, other activities and people around them, and absorption in any given task. Absorption could be likened to Csikszentmihalyi's (1990) state of 'flow', described as a 
Table 1 Potential behaviours and capabilities underpinning success in technology

\begin{tabular}{llllll}
\hline Behaviours & Resilience & Transference & $\begin{array}{l}\text { Flexibility and } \\
\text { sophistication }\end{array}$ & Reflection & Socialisation \\
\hline Capabilities & Perseverance & Making links & Planning & Questioning & Empathy and listening \\
& Managing & Imaging & Distilling & Distilling & Collaboration \\
& Distractions & Noticing & Reasoning & Revising & Interdependence \\
& Absorption & Questioning & Imagining & Meta learning & Imitating \\
& & & Capitalising & Evaluating & \\
& & & Evaluating & & \\
\hline
\end{tabular}

state of deep absorption in an activity that is intrinsically enjoyable, as when artists and athletes are focused on their play or performance (Shernoff et al. 2003).

Transference included making links to technologies experienced or seen, and experiences undertaken previously such as using existing cultural knowledge and experiences or Funds of Knowledge which have been found by González et al. (2005) and Fox-Turnbull (2012) to inform student learning. It also included imaging how existing knowledge and skills might be transferred to new situations.

Flexibility and sophistication indicated an increased depth to understanding, as well as an openness to new and potentially strange ideas. Embedded in this behaviour were reasoning and distilling information aimed at assisting understanding and questioning of others. Planning ideas, actions and making the best use of resources also characterised this behaviour. Recent research suggests there is an intuitive connection between creativity and cognition (Lewis 2008; Runco 2014), Spendlove (2015) identified strong societal benefits of being creative within technology education, therefore increased sophistication of ideas as the potential to improve creativity and innovation during design and technology.

Reflection described the strategic and self-managing aspect of learning including the planning and anticipation of needs and issues, distilling information for potential use, revision of prior learning and identification of learning that can be transferred to a new context, self-generated questioning and monitoring progress through cognisance of what, how and why learning occurs.

The fifth behaviour was socialisation. The inherently social nature of technology practice and the physical, social and environmental impacts of technology made inclusion of this behaviour vital. Whether engaged in the use of, or development of technological outcomes students interacted in a social manner. Through collaboration with others, students experienced interdependence with a balancing of self-reliance and socialisation.

Following the identification of the above behaviours the TOCF ("Appendix"-primary version) was constructed by tabulating the behaviours across the five common aspects of technology practice. The capabilities were used to break down each behaviour and guided the identification of key questions for teachers to ask, comments to say and actions to observe when teaching technology with the aim of enhancing teachers' PCK and content knowledge through the recognition of knowledge and behaviours situated within students' technology activity. 


\section{The study: methodology and methods}

This study contributes to understandings of teaching technology using a tool specifically designed to facilitate quality teacher-student interaction aimed at developing teachers' understandings of TCK and TPCK. The research was situated within an interpretative paradigm aimed at understanding human experience while maintaining integrity of the phenomena studied, in this case teaching (Cohen et al. 2011). Sociocultural theory informed the qualitative research method. Ritchie et al. (2014) suggest these are a good match. Two fundamental themes define sociocultural research: action and mediation. Drawing selectively from insights of both Vygotsky and Leont'ev, Wertsch (1998) stated that an underlying assumption of socio-cultural theory was that humans access the world indirectly through the use of tools, rather than directly. External tools mediate action allowing internalisation into mental action (Zinchenko 1985). The tool in this study, the TOCF, was used by teachers to assist them in their observation of and conversations with students during technology. The framework was designed to facilitate the development of teacher TCK and TPCK, by assisting them in the identification of key aspects in technology practice and enabling them to give relevant formative feedback to students. Clarke (2014) stated that the giving of timely formative feedback to students assisted learning. The framework guided teachers through suggested questions, comments and observations.

Research methods included semi-structured interviews before and after using the TOCF, researcher observations of the teachers with the framework in action and the researcher reflections. Observation of the teachers occurred as they worked with their students, using the TOCF to guide them. The focus of the study was the teachers' experience with the framework and how it developed their understanding of teaching and learning in technology. Ethical approval for the study was gained. Confidentiality of data was assured for schools, teachers, and students as was anonymity. All participants were voluntary and able to leave the study at any time.

Data was gathered over a six-month period in 2016. The main data came from semistructured interviews with six teachers, both before and after using the framework. The teachers were initially interviewed to identify their current knowledge of and experience in teaching technology. The initial semi-structured interviews were followed by a professional development session on the background and use of the framework. All participants were given the framework well before the first observation session. All spent time reading the framework as selecting aspects which best suited their situation. They then used the questions, points of observations and suggested comments to facilitate technology practice in the classroom. Data was triangulated through researcher observations and video recordings of teachers' conversations with students.

Data analysis occurred through repeated coding and recoding as suggested by Neuman (2011) and Cohen et al. (2011) to facilitate description of the teachers' experiences using the framework. The primary version of the framework was slightly modified after the first round of data gathering in New Zealand before further data gathering occurred in England. The early childhood version was used in Sweden. The framework was again modified after all the initial interviews were undertaken, taking into account teachers' feedback. 


\section{The participants}

Six teachers took part in the study, two from New Zealand, England and Sweden. All teachers taught children between the ages of four and six years of age. In Sweden in an early childhood setting, in New Zealand a primary setting and in England the school included both early childhood and primary children, although technology learning occurred in a primary facility. Pseudonyms were used to protect the identity of the teachers.

- Teacher 1 (M) from New Zealand, had taught for nine years and learned technology education as a part of his initial teacher training. He enjoyed teaching technology although admitted he was not hugely experienced at it.

- Teacher 2 (Am) from New Zealand, was a beginning teacher who had no specific technology education in her initial; teacher training programme. She had never taught technology before the study but did observe it being taught on one of her practicums.

- Teacher $3(\mathrm{~K})$ from England, was an experienced primary teacher of nine years who had moved into entirely teaching technology three years previously. $\mathrm{K}$ had no formal training in technology before obtaining her position. She took a number of classes to upskill herself in technology but was given limited professional development in the technology curriculum.

- Teacher 4 (J) from England, was a very experienced primary teacher with 19 years' experience. She then took an 18-year break before joining her current technology department as a specialist teacher assistant. When entering her current department, she was given some ad hoc professional development in safe use of machinery.

- Teacher 5 (Je) from Sweden, had 18-year teaching experience working with students from 1 to 6 years of age. As an early childhood education (ECE) trained teacher she received no technology education training in her initial teacher education programme.

- Teacher 6 (An) from Sweden, was also an experienced teacher of 19 years who worked with students from 1 to 6 years of age. Again, as an ECE trained teacher she received no technology education training in her initial teacher education programme but was heavily influenced by the Reggio Emilio philosophy of teaching.

All teachers had similar understanding of technology education at the point of the first interview, although they had come to these understandings very differently. All understood that technology was about the 'made world' and that students not only designed and developed technological outcomes but also needed to understand the impacts of technology on people and places. Only M had had technology included into his initial teacher education training. Both $\mathrm{K}$ and $\mathrm{J}$ had received some training when they began their technology teaching. Both $\mathrm{K}$ and $\mathrm{J}$ taught only technology as a part of a specialist team of technology teachers, however they had sole responsibility for teaching technology for students from four to 10 years of age within their school. As they were trained in early childhood education neither Je nor An had considered technology teaching as a formal part of their responsibility. Am was aware of technology in the curriculum and although she had never taught it she had observed its teaching while training to become a teacher. 


\section{Findings}

Teacher interviews were transcribed, researcher notes read and observation footage viewed to identify early themes relating to the teachers' experiences and views of the framework. These were (1) developed insights into students' learning, (2) teachers' ability to prepare for teaching technology and (3) an understanding that the quality of students' technology outcomes and the quality of their learning were not necessarily connected. Further coding and analysis led to the identification of the final themes, one related to gains in teachers' TCK and three related to teacher PCK. The themes identified teachers' views of gained insights into (1) understanding technology, (2) key aspects of learning technology, (3) the benefits for students when their teachers used the framework, (4) the benefits of conversation in learning technology. One final theme emerged related to recommendations for future framework development. This article focuses on the themes relating to development of teacher TCK and TPCK, each with two or three sub-themes as outlined in the Table 2.

\section{Understanding technology}

Development of a teacher's pedagogical content knowledge relies on and develops with sound content knowledge and pedagogical knowledge (Gudmundsdottir and Shulman 1987; Shulman 1986). Teachers felt the framework developed their personal understanding of technology in a number of ways. $\mathrm{M}$ and Am found that using the TOCF developed their understanding of aspects of technology practice such as the role evaluation of technological outcomes plays in technology practice: "I think for me it's actually the plan and the make and the most important is the evaluate." (M) "And yeah I would agree that the idea that planning, making and then evaluating that they go hand in hand and it's not something you do in isolation" (Am) and "teaching that idea of planning and evaluating [technology outcomes] [is important] because it builds in that critical thinking"(Am). K thought the framework assisted her understanding that students need to consider a range of stakeholders in their practice.

So we often ask things like why does it work, how does it work what materials/ the properties of materials, things like that. The questions like 'what would you like to ask the person who made this' to find out about how and why it works. Different questions, that we hadn't thought of, different perspectives, and then sort of going that bit deeper with, certainly the older chn, but as you say, even starting too with the younger chn. Higher order stuff.

An developed an understanding that technology is not just about technology we have currently, but rather it applies to technologies of the future as well, "I think we have to work on a deeper level with children in technology and in early age to give them all the possibilities to develop the technology of tomorrow for years and years ahead". Jn developed her understanding of the complexity of technology as a curriculum area, "So many sides of technology, [the framework] does help you, pick up many sides of technology", and she further showed her understanding of technology later by indicating that it involved everyday technologies and not only complex ones, "It [technology] helps us, I think technology, oh it's how the phone works, or how, its, I think we are thought that it's very complex, but it's so easy because we are living it". 


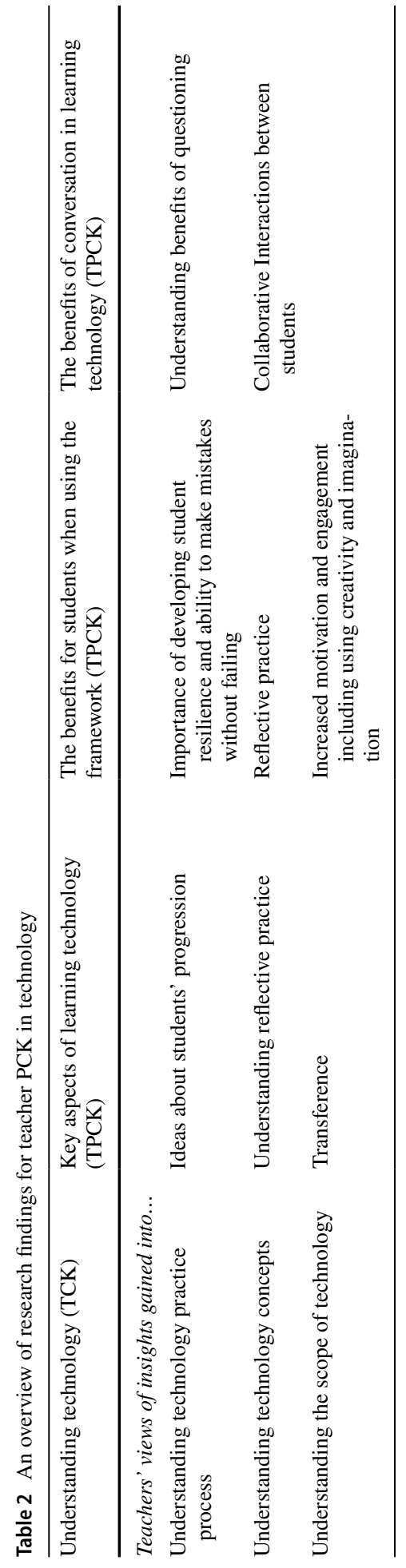




\section{Key aspects of learning technology}

Teachers stated they gained a better understanding of students' learning in technology in numerous ways, "The framework helped me to see that we can help the children even further in their progression of learning technology than we try to do today" (An). Participants also felt they gained an understanding of student technology practice and the role of reflection in student learning in technology as illustrated by Am,

They were really reflective and quite honest during that process... They were very self-critical, which was interesting .... as it doesn't come naturally to this age. So we were able to seem them develop those skills of being critical of their own work and their own thinking. It was quite incredible.

And this by An, "It has been fantastic to see how the children worked with the material and trying to build things from the real world, or new creative constructions that they are proud of". M realised that students were making ongoing design decisions to improve outcomes.

I think the conversations of some of the kids, I was going to use paper', 'well why didn't you use paper?' 'Because paper wasn't strong enough so that had to change' showed that they understood that it was still their design, but they have made these changes to make it stronger.

Teachers also developed insight into how students transferred knowledge from other areas of their lives to technology. In Sweden Jn had the students engaged in designing a three-dimensional railway, "They had that three-dimensional thing in their mind and then they pick up trains and try to use it so I saw we could work together". The students selected the context themselves, and Jn noted that most students used the train regularly with their parents and some parents were employed in railway construction, "It is very big project and for trains too, so I think, and we have parents who work to build train[s]" (Jn). In England K was impressed how her students transferred collaborative skills to technology to achieve positive results".

I thought it was one of those moments as a teacher where you go, they were there, they were listening. It had sunk in, it had made a difference. It wasn't just me going blah blah blah. That gave me great joy, really gave me great joy, 'cos that's a life skill and they transferred it.

The following extracts indicate that the teachers identified that the students were very motivated and engaged in their learning and motivated to do a good job, "I asked them how they learned to build so fantastic together. For a month ago we built separately, and now we build together. So we have learned to use each other" (Jn). Am stated "It was quite exciting for them to feel like they were the creators and inventors of somethings". She was also able to recognise the importance of authentic technology practice.

I think because it was relevant to them so the idea that technology just this sort of farfetched thing for the professional, it can be something that relates to your needs and your life and the people around you so they kind of realised. 'Ok so I might not grow up to be a person who designs technology but I can still follow that process now through to the end', which is something quite cool. 
Teachers also noted how seriously the students took their work and engaged in their technology practice as illustrated by Am.

It was like a fun activity but to see how seriously they took it. It was like 'this is my plan and I've got these materials and I need to make it'. They were thinking about how they were going to make it and what it was going to look like at the end.

Finally in this section An realised that there was still a great deal to learn about teaching technology to children, "I have learned that there is more for me to learn about how children learn technology".

\section{Benefits for students}

Teachers identified three main benefits for students when they [the teachers] used the framework: developing resilience, ability to being reflective and increased motivation and engagement. In New Zealand the teachers specifically commented on the need for the students to develop resilience. On seeing the framework for the first time $\mathrm{M}$ commented on the need for his students to develop resilience as they tended to give things a go once and then give-up as evidenced by the following extract from the researcher's journal, " $\mathrm{M}$ very enthusiastic and excited. Could immediately see the applications in resilience particularly" (Researcher Journal 15 June 2017). This understanding also assisted the teachers $M$ and Am's recognition of resilience within the students later in their project.

...so they understood that there wasn't a process of failure but that is something that everybody does and you can always look for what you can do better, and it was like 'Oh, Okay!' Mr M and Miss Am can make mistakes so therefore so can I, I can admit them because it's not that I have failed.

In New Zealand Am identified that when she used the framework the students were given more opportunity to be reflective, "They were really reflective and quite honest during that process". M identified increased thinking, "I got some really amazing higher order thinking from the kids by asking the questions". In Sweden An developed insight into her role in this, "Yes, I now see how valuable it is for the children to be able to develop more of their technology skills on a deeper level and that I as their teacher has to make it possible for them. In England $\mathbf{J}$ found that her students appeared to feel better about asking questions, "It's made the kids think that it's much easier, or much more acceptable to ask for help'.

The teachers noticed the students were motivated and engaged during their technology activity illustrated through the flowing quotes: "It was quite exciting for them to feel like they were the creators and inventors of somethings" by Am of New Zealand and Jn from Sweden "It's ah they have so fun, and its creating and they want to help each other, and they wanted to make it" and "Intense and focused, focus, um, they have, their eyes on it all the time and they have a motor inside, driving inside" Jn.

\section{Benefits of conversation}

Teachers gained insight into the benefits of the questions and engaging students in conversation, illustrated by $\mathrm{M}$ in the following quote. 
It was so amazing really to see how much the questioning did enrich the learning and how it kind of lifted it up a level from where it would have been in the past.....Children think at higher levels.

J indicated a stronger understanding of the role of questioning, "It made me think about the questions a lot more because you highlighted those things, it made me think about the language".

A number of the teachers recognised the students were motivated to work collaboratively and how they talked and learned from each other. Jn was surprised to see her four and five-year olds working together.

Yeah, and solve problem, and I think 'It's possible to do it' ....... and they can do it together, and they find material, so built together to, and have own ideas when they [are] collaborating together"

M recognised that the younger students learned from the older students in his class.

The kids were witnessing others, old children how they were using the equipment and things like that. They were learning through others which kind of took about of pressure off the teachers

Teachers also observed that students were also able to recognise that working with other people assisted their learning.

When we asked, 'How did working with someone else help you?' and they kind of stopped and went 'Yeah it did help' or they'd say 'No that didn't help', but they would stop and think about it and then give reasons why it was helpful" (M).

\section{Discussion and conclusion}

The triad of pedagogical knowledge, content knowledge and pedagogical content knowledge (Gudmundsdottir and Shulman 1987; Shulman 1986) are well illustrated in the study. The TOCF facilitated close observation and deep questioning of students when they were engaged in technological practice. Teachers believed that the process enhanced their understanding of technology and TCK. This in turn gave them critical insight into strategies and activities that assisted students' learning in technology and thus developed their TPCK.

Snape and Fox-Turnbull $(2011,2013)$ state that technology and the principles of 21st Century learning are particularly compatible. This study supports this through the identification of desirable 21st Century behaviours particularly relevant to technology. Use of the TOCF assisted in participants' understanding and teaching of technology by giving them insight into learning behaviours across aspects of technology. The study found that teachers tended to focus on one or two aspects of the framework at a time. This was expected as the aspects of the framework are related to the stages of technology practice which tend to be undertaken in a somewhat chronological manner. Although there is no one design process technology practice goes through a number of logical stages as students investigate, design and develop their technological outcomes (Kimbel et al. 1996). In New Zealand and Sweden, teachers focused on the aspect of Design, Make and Evaluate. In England Understanding the Technological World and Evaluate Current Technologies were the foci. All teachers indicated that the other aspects would be useful in other units or projects, especially with the framework available during the teacher planning process. 
When using the TOCF teachers drew on questions from all five behaviours, suggesting technology facilitates opportunities for engagement in a range of desirable 21st Century behaviours as outlined by Bellanca and Brandt (2010), Claxton and Carr (2010) and Claxton et al. (2013). Teachers in this study stated that they could see the benefits of students developing resilience through the understanding that making mistakes in technology is a normal and indeed useful part of technology practice, rather than failure. This supported Claxton et al. (2013) stance on the role of resilience plays in successful learning. Transference was also identified by the teachers as making a positive contribution to students' learning in technology. In all classrooms students were clearly influenced and brought their Funds of Knowledge to their activity, as particularly illustrated by the students in Sweden who designed a complex railway system. This supports in the literature on Funds of Knowledge (Fox-Turnbull 2012; González et al. 2005) that states students benefit from funds of knowledge transference to classroom learning, especially in technology (Fox-Turnbull 2013).

The framework assisted teachers' recognition of the need to develop higher level skills and abilities of their students in technology. The study clearly illustrated that higher level questioning, reflection and collaboration played an important part in developing deep understandings of technology and technological practice. Teachers in England, including $\mathrm{K}$ who was the most experienced technology teacher highlighted 53 of the 91 questions from the framework that they had previously or regularly used. Teachers in New Zealand and Sweden commented on how the questions assisted their teaching practice in technology. The ability for students to work collaboratively and to be reflective and self-critical surprised all the participants. The findings from the study clearly support Wagner's (2008) proposed essential modern survival skills and Claxton and Carr's (2010) dispositions necessary for learning and ability to build learning power (Claxton et al. 2013). Collaborative technology practice is common place in the real world, but perhaps less so in technology education, especially with young students, perceived as not being able to work well collaboratively. This study indicates that collaborative practice not only occurs in technology but that students benefit from working with their peers, as was illustrated in both New Zealand and Sweden and supports Fox-Turnbull's (2013) study on the role of conversation in learning. Teachers developed insight into a range of ways students were able to work collaboratively, even at quite young ages.

Limitations of the study were that there was no formal measurement of teachers' TCK and TPCK undertaken. Also, no measurement of students' progress was taken so teachers' ideas about their own learning and that of their students were subjective. There is therefore potential here for a further study using the framework in quantitative study to formally measure these changes. Another limitation of the study was timeframe; teachers did not have the framework while planning their technology teaching. Increased and earlier engagement with the framework may have altered results.

In conclusion the study's participants stated that using the TOCF assisted their understanding of how and what to teach in technology education and in helping their students' development in technology through the identified behaviours and across the identified aspects of technology. A further study could apply the framework over a larger number and wider range of students, in terms of ages, culture and nationality and accurately measure the impact of learning for students. Changes in teachers' understanding of technological pedagogical and content knowledge that occurred while using the framework could also be studied.

\section{Appendix}

See Table 3. 


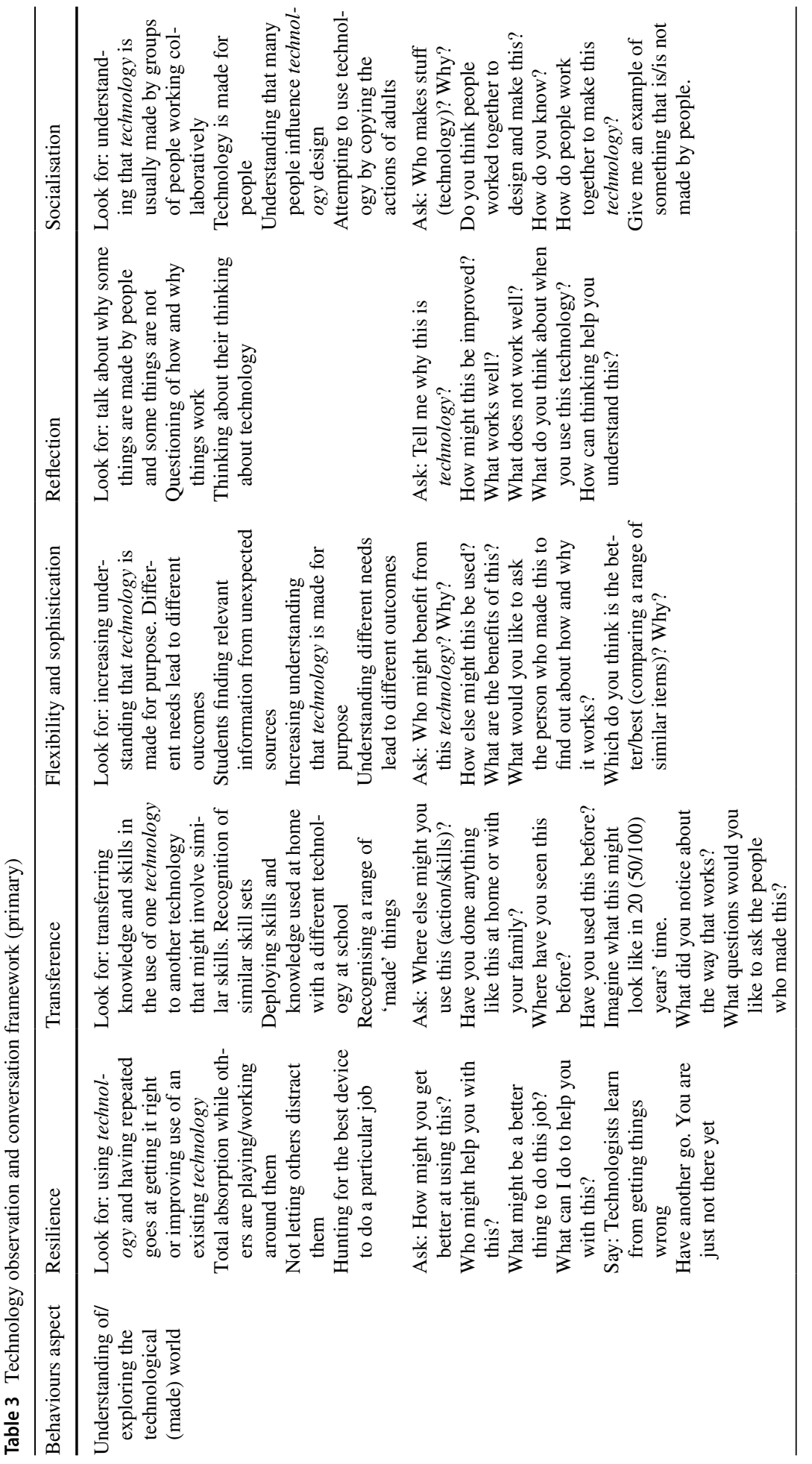




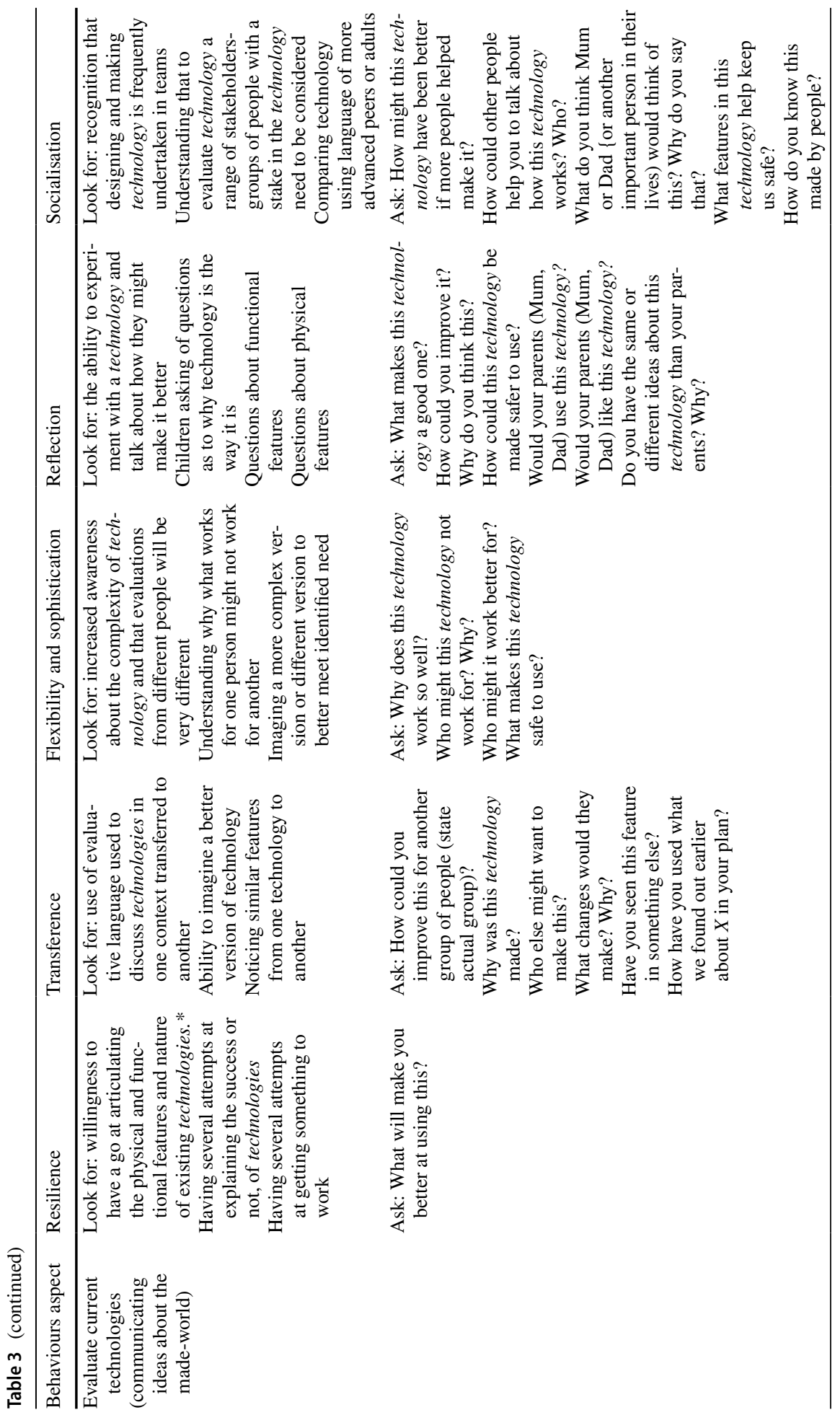




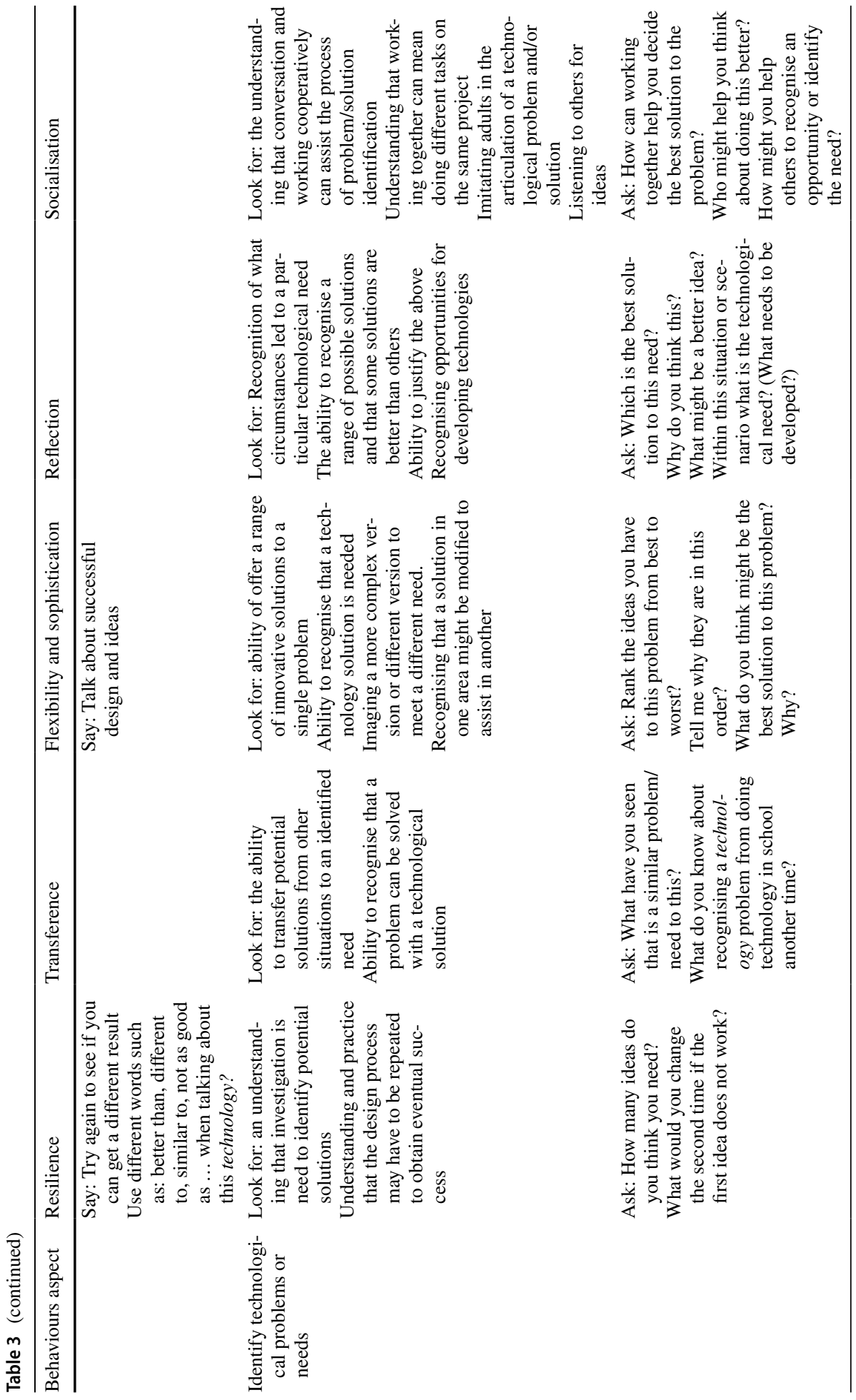




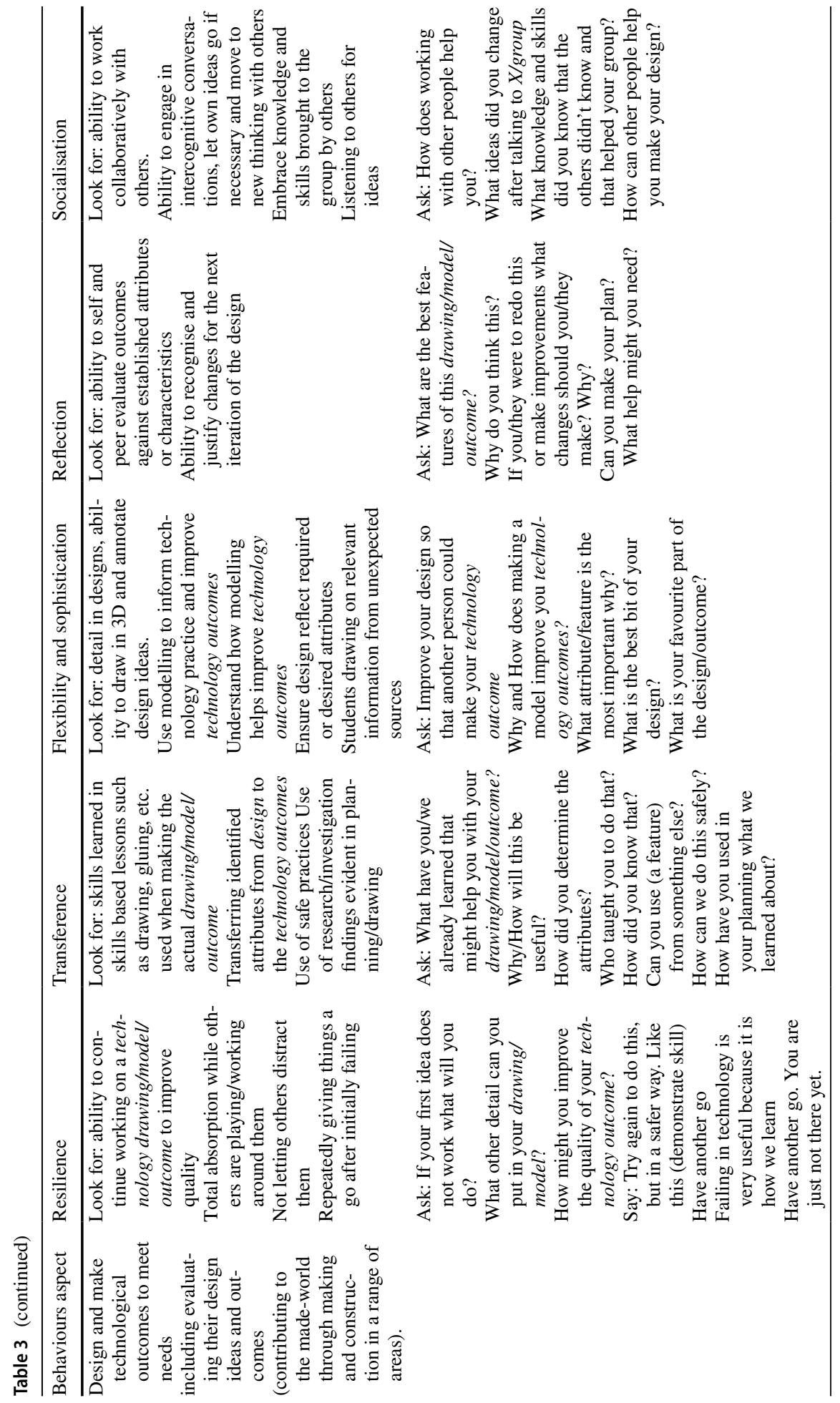




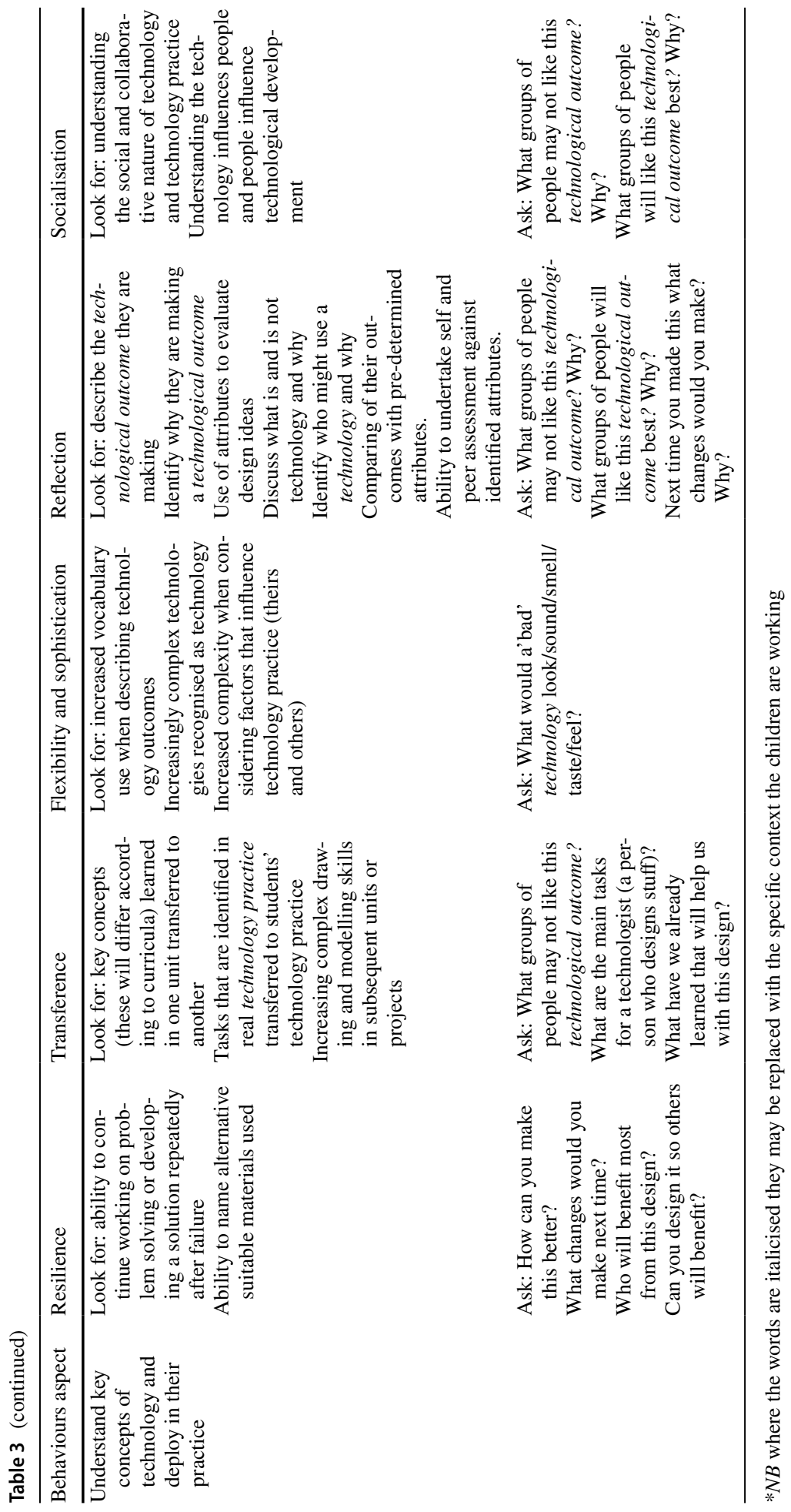




\section{References}

Alexander, R. (2008). Towards dialogic teaching: Rethinking classroom talk (4th ed.). Cambridge: Dialogos.

Bellanca, J., \& Brandt, R. (Eds.). (2010). 21st century skills: rethinking how students learn. Bloomington: Solution Tree Press.

Clarke, S. (2014). Outstanding formative assessment: culture and practice. London: Hodder Education.

Claxton, G., \& Carr, M. (2010). A framework for teaching learning:the dynamics of disposition. Early Years: An International Journal, 24(1), 87-97.

Claxton, G., Chambers, M., Powell, G., \& Lucas, B. (2013). The learning powered school: Pioneering 21st century education. Bristol: Bristol TLO Limited.

Cohen, L., Manion, L., \& Morrison, K. (2011). Research methods in education. London: Routledge.

Compton, V., \& France, B. (2007). Towards a new technological literacy: Curriculum development with a difference. Curriculum Matters, 3, 158-175.

Compton, V., \& Harwood, C. (2005). Progression in technology education in New Zealand: Components of practice as a way forward. International Journal of Technology and Design Education, 15, 253-287.

Cross, A. (2011). In search of a pedagogy for primary design and technology education. In C. Benson \& L. Lund (Eds.), International handbook of primary technology education (Vol. 7, pp. 167-180). Rotterdam: Sense Publishers.

Csikszentmihalyi, M. (1990). Flow: The psychology of optimal experience. New York: Harper-Perennial.

de Vries, M. (2017). Philosophy of technology: Themes and topics. In M. de Vries (Ed.), Handbook of technology education (pp. 7-16). Cham: Springer.

Department of Education. (2013a). The national curriculum in England: framework document. London: Department of Education. Retrieved from www.gov.uk/dfe/nationalcurriculum.

Department of Education. (2013b). Statutory guidance: national curriculum in England: Design and technology programmes of study. Retrieved from https:/www.gov.uk/government/uploads/system/uploads/ attachment_data/file/425601/PRIMARY_national_curriculum.pdf.

Doyle, A., Seery, N., Gumaelius, L., Donal Canty, D., \& Hartell, E. (2018). Reconceptualising PCK research in D\&T education: Proposing a methodological framework to investigate enacted practice. International Journal of Technology and Design Education, pp. 1-19. https://doi.org/10.1007/s1079 8-018-9456-1.

Fox-Turnbull, W. (2006). The influences of teacher knowledge and authentic formative assessment on student learning in technology education. International Journal of Technology and Design Education, 16, 53-77.

Fox-Turnbull, W. (2012). Funds of knowledge in technology education. Paper presented at the PATT 26 Stockholm, Sweden.

Fox-Turnbull, W. (2013). Themes of conversation in technology education. In: Paper presented at the International Teachnology and Engineering Educators' Assocation Conference, Columbus.

Fox-Turnbull, W. (2016). The nature of primary students' conversation in technology education. International Journal of Technology and Design Education, 26(1), 21-41.

González, N., Moll, L. C., \& Amanti, C. (Eds.). (2005). Funds of knowledge (1st ed. Vol. 2009 Reprint). New York: Routledge.

Gudmundsdottir, S., \& Shulman, L. (1987). Pedagogical content knowledge in social studies. Scandinavian Journal of Educational Research, 31(2), 59-70. https://doi.org/10.1080/0031383870310201.

Hope, J. (2018). Mastering primary design and technology. London: Bloomsbury Academic.

Hulten, M., \& Bjorkholm, E. (2016). Epistemic habits: primary school teachers' development of pedagogical content knowledge. International Journal of Technology and Design Education, 26(3), 335-351.

Jones, A. (2009). Towards an articluation of students making progress in learning technological concepts and processes. In A. Jones \& M. de Vries (Eds.), International handbook of research and development in technology education. Rotterdam: Sense Publishers.

Kimbell, R. (1997). Assessing technology international trends in curriculum and assessment. Buckingham: Open University Press.

Kimbell, R., Stables, K., \& Green, R. (1996). Understanding practice in design and technology. Buckingham: Open University Press.

Lewis, T. (2008). Creativity in technology education: Providing children with glimpses of their inventive potential. International Journal of Technology and Design Education, pp. 255-268. Retrieved from https://doi.org/10.1007/s10798-008-9051-y.

Masson, A.-L., Klop, T., \& Osseweijer, P. (2016). An analysis of the impact of student-scientist interaction in a technology design activity, using the expectancy-value model of achievement related choice. International Journal of Technology and Design Education, 26(1), 81-104. 
Mercer, N. (1995). The guided construction of knowledge-talk amongst teachers and learners. Bristol: Multilingual Matters Ltd.

Mercer, N., \& Dawes, L. (2008). The value of exploratory talk. In N. Mercer \& S. Hodgkinson (Eds.), Exploring talk in school (pp. 55-71). London: Sage Publications Ltd.

Mercer, N., \& Hodgkinson, S. (Eds.). (2008). Exploring talk in school. London: Sage Publications Ltd.

Mercer, N., \& Littleton, K. (2007). Dialogue and the development of children's thinking-a sociocultural approach. Oxon: Routledge.

Ministry of Education. (1996). Te Whāriki early childhood curriculum. Wellington: Learning Media.

Ministry of Education. (2007). The New Zealand curriculum. Wellington: Learning Media.

Moreland, J., \& Jones, A. (2000). Emerging assessment practices in an emergent curriculum: Implications for technology. International Journal of Technology and Design Education, 10(3), 283-305.

Moreland, J., Jones, A., \& Chambers, M. (2001). Enhancing student learning in technology through teacher technological literacy. Wellington: University of Waikato.

Neuman, W. L. (2011). Social research methods: Qualitiative and quantitative approaches. Boston: Pearson.

Osborne, J. (2009). Learning to argue, aruing to learn. In A. Jones \& M. De Vries (Eds.), International handbook of research and development in technology education (pp. 431-444). Rotterdam: Sense Publishers.

Pellergrino, J. W. (2002). How people learn: contributions to framing a research agenda for technology education (Vol. 2). Gold Coast: Centre for Technology Education Research.

Ritchie, J., Lewis, J., McNaughton Nicholls, C., \& Ormston, R. (Eds.). (2014). Qualitative research practice: A guide for social science students and researchers. London: Sage Publications Ltd.

Rohaan, E. (2009). Testing teacher knowledge for technology teaching in primary schools. Eindhoven: Eindhoven University of Technology Library.

Runco, M. A. (2014). Creativity: theories and themes: Research, development, and practice (2.th ed.). London: Academic Press Elsevier.

Shernoff, D. J., Csikszentmihalyi, M., Schneider, B., \& Shernoff, E. S. (2003). Student engagement in high school classrooms from the perspective of flow theory. School Psychology Quarterly, 18(2), 158-176.

Shields, C., \& Edwards, M. (2005). Dialogue is not just talk- a new ground for educational leadership. New York: Peter Lang Publishing Inc.

Shulman, L. S. (1986). Those who understand: Knowledge growth in teaching. Educational Researcher, 15(2), 4-14.

Snape, P., \& Fox-Turnbull, W. (2011). Twenty-first century learning and technology education nexus. Problems of Education in the 21st Century, 34, 149-161.

Snape, P., \& Fox-Turnbull, W. (2013). Perspectives of authenticity: implementation in technology education. International Journal of Technology and Design Education, 23(1), 51-68. https://doi.org/10.1007/ s10798-011-9168-2.

Spendlove, D. (2015). Developing a deeper understanding of design. In P. J. Williams, A. Jones, \& C. Bunting (Eds.), The future of technology education: Contemporary issues in technology education series. Singapore: Springer.

Turnbull, W. (2002). The place of authenticity in technology in the New Zealand curriculum. International Journal of Technology and Design Education, 12, 23-40.

Wagner, T. (2008). The global achievement gap: why even our best schools don't teach the new survival skills our children need--and what we can do about it. New York: Basic Books.

Wertsch, J. (1998). Mind as action: The task of sociocultural analysis. New York: Oxford University Press.

Williams, J., Eames, C., Hume, A., \& Lockley, J. (2012). Promoting pedagogical content knowledge development for early career secondary teachers in science and technology using content representations. Research in Science \& Technological Education, 30(3), 327-343. https://doi.org/10.1080/02635 143.2012.740005.

Yliverronen, V. (2018). Preschoolers' peer collaboration on a designing task. Design and Technology Education: An International Journal, 23(2), 106-128.

Zinchenko, V. P. (1985). Vygotsky's ideas about units for the analysis of mind. In J. Wertsch (Ed.), Culture, communication, and cognition (pp. 94-118). Cambridge: Cambridge University Press. 